\title{
A NOTE ON ESTIMATING THE IMPORTANCE OF INTERACTIONS AMONG ECONOMIC ENTITIES
}

\author{
Emilian Dobrescu* \\ Romanian Academy, Bucharest, Romania
}

\begin{tabular}{|l|l|}
\hline Please cite this article as: & Article History \\
Dobrescu, E., 2019. A Note on Estimating the & Received: 15 February 2019 \\
Importance of Interactions among Economic Entities. & Revised: 5 May 2019 \\
Amfiteatru Economic, 21(52), pp. 671-681. & Accepted: 17 June 2019 \\
& \\
DOI: $\mathbf{1 0 . 2 4 8 1 8 / E A / 2 0 1 9 / 5 2 / 6 7 1}$ & \\
\hline
\end{tabular}

\begin{abstract}
In a maximally simplified scheme, the economy is an immense network of interacting entities (individuals, households, firms, institutions, regions, countries, international unions), reducible in the last instance to an, again, huge graph of transactions (in the largest sense). Well known couples as seller-buyer, lender-borrower, exporter-importer, tax payer-fiscal authority etc. personify this double-entry framework. The national accounts, input-output tables, general equilibrium models are several modalities to configure and study this complicated system in a coherent framework. A theoretical and applicative challenge continues to be "how to evaluate quantitatively the relative importance of a given concrete transaction from the perspective of the entire economy (the totality of transactions)". The present note tries to answer to such a problem starting from the positions detained in economy by the involved in transactions entities. As an applicative example, there are used the Romanian yearly input-output tables for 1989-2016.
\end{abstract}

Keywords: transaction, $\mathrm{W}$ matrix, $\mathrm{HH}$ index

JEL Classification: C43, C67

*Author's contact: emdobrescu1@gmail.com 
1. In a maximally simplified scheme, the economy is an immense network of interacting entities (individuals, households, firms, institutions, regions, countries, international unions), reducible in a last instance to an - again huge, hardly imaginable - graph of transactions (in the largest sense). Well known couples as seller-buyer, lender-borrower, exporter-importer, tax payer-fiscal authority and so on personify this double-entry framework. The national accounts, input-output tables, general equilibrium models are several examples of tools to represent and study this complicated system in a coherent framework. A theoretical and applicative challenge continues to be "how evaluate quantitatively the relative importance of a given concrete transaction from the perspective of entire economy (the totality of transactions)".

As a rule, the transactions can be appreciated from many points of view, respectively $\mathrm{m}$ criteria $X_{k}(k=1,2, \ldots, m)$. The importance of a given transaction can be appreciated:

i) relative to either one $X_{k}$ which presupposes aggregability of transactions according to this criterion, and

ii) relative to several or all $X_{k}$ which involves supplementary the aggregability of the concerned $\mathrm{X}_{\mathrm{k}}$ in cause.

The present note attempts to be a contribution to the discussions around the first question. Since we shall refer to a single criterion, hereinafter the subscript $\mathrm{k}$ will be omitted.

2. An intuitive and easy understandable such framework is also the extendedly used inputoutput tables. Consequently, our discussion will be centered on this example. There exist, therefore, $\mathrm{n}$ operators, linked by transactions $\mathrm{x}_{\mathrm{ij}}$, where their position as suppliers conventionally is noted by $i(i=1,2, \ldots, n)$, while that as users by $j(j=1,2, \ldots, n)$. The first hypostasis of operators is described on rows of matrix, and the second one on columns.

2.1. It seems reasonable to evaluate the importance of a given transaction in dependence on importance assignable to the involved operators (noted $\Phi$ ), in virtue of their positions within respective field. For such a role, it is expectable to choose such indicators that generate as a rule positive $\Phi$ (for instance: production, turnover, accumulated assets etc.). Our analysis operates with this assumption.

2.2. As mentioned, the present proposal assumes also that $\sum \Phi_{\mathrm{i}}=\Phi_{\mathrm{a}}$, where $\Phi_{\mathrm{a}}$ is the indicator in cause, calculated for the whole ensemble of considered entities. Under such a condition, it would be convenient to transform $\Phi_{\mathrm{i}}$ into normalized magnitudes $\varphi_{\mathrm{i}}=\Phi_{\mathrm{i}} / \Phi_{\mathrm{a}}$ which means $\sum \varphi_{i}=1$. The positivity of $\Phi_{i}$ involves automatically non-negativity of $\varphi_{i}$.

2.3. The main assumption of the present empirical study is that the relative importance of a transaction between entities $\mathrm{i}$ and $\mathrm{j}$ (noted $\mathrm{w}_{\mathrm{ij}}$ ) is measured as a simple product of $\varphi_{\mathrm{i}}$ and $\varphi_{\mathrm{i}}$, i.e. $\mathrm{w}_{\mathrm{ij}}=\varphi_{\mathrm{i}}{ }^{*} \varphi_{\mathrm{i}}$.

3. The Romanian input-output tables were adopted as an experimental database. Their building has been guided by the generally used conceptual and methodological framework (Leontief, 1936, 1970, 1986; Stone, 1961; United Nations, 1999; Wixted et al., 2006; European Commission, 2008; Miller and Blair, 2009). The Leontiev variant was promoted.

The used series were elaborated (in cooperation with V. Gaftea) using the officially published tables of the Romanian statistical office. The series were organized firstly on the basis of NACE Rev.1 (ESA 79 methodology), and afterwards according to ESA 2010 NACE Rev. 2 (Commission Regulation EU - No 715/2010, 2010); for details see INS 2016. The data 
methodologically homogenized this way for 88 branches were aggregated into a more compact structure (initially six and subsequently ten sectors, and recently fourteen sectors). The I-O tables were integrated into the macromodel of the Romanian economy (Dobrescu, 2006a, 2006b, 2015; Dobrescu and Gaftea, 2017). The last classification comprises (in brackets the corresponding adopted code):

- Agriculture, forestry, hunting and fishing (1);

- Mining and quarrying (2);

- Production and distribution of electric and thermal power (3);

- Food, beverages and tobacco (4);

- Textiles, leather, pulp and paper, furniture (5);

- Machinery and equipment, transport means, other metal products (6);

- Other manufacturing industries (7);

- Constructions (8);

- Transports, post and telecommunications (9);

- Trading services (10);

- Financial services and real estate transactions (11);

- Social services (12);

- Creative services (13); and

- Professional services (mainly businesses) (14).

4. For this structure there were estimated the importance weights $\mathrm{w}_{\mathrm{ij}}$, adopting as proxy of $\varphi_{\mathrm{i}}$ the shares $\left(\mathrm{q}_{\mathrm{i}}\right)$ of sectoral outputs $\mathrm{i}\left(\mathrm{Q}_{\mathrm{i}}\right)$ to the total output of economy $(\mathrm{Q})$ : therefore $\sum \mathrm{q}_{\mathrm{i}}=1$. In this interpretation, the extremal cases are purely fictive sectors (with q situated in zero proximity) and completely mono-sectoral economy (with q equal to unity for a certain sector). Obviously, these are only hypothetical, real economy - the Romanian also - being characterized by $0<\mathrm{q}_{\mathrm{i}}<1$.

Technically, the $\mathrm{n}$-dimensional matrix $\mathrm{W}$ results by multiplying the row-vector $\mathrm{q}_{\mathrm{i}}$ with its transposed form. Evidently, the operation can be realized symmetrically, starting from identical column-vector $\mathrm{q}_{\mathrm{j}}$

5. The matrix $\mathrm{W}$ has several notable properties:

- Since by definition $\mathrm{q}_{\mathrm{i}}>0$ the weights $\mathrm{w}_{\mathrm{ij}}$ are also non-negative.

- The sums of the same order row and column are equal, which means that any sector has an identical importance either as supplier or buyer. Such a peculiarity is important in our analysis.

- It is easy to observe that the elements situated on the main diagonal (which runs from top left to bottom right) of the matrix $\mathrm{W}$ are the squared $\mathrm{q}_{\mathrm{i}}$. In other words, the sum of this 
diagonal represents the Herfindahl-Hirschman index. (Hirschman, 1958; U.S. Department of Justice and the Federal Trade Commission, 2010; Mereuta, 2019).

6. Temporally, the matrix $\mathrm{W}$ reflects the global post-socialist evolution of Romania.

6.1. Three phases can be distinguished along this complex process.

a) The decade 1990-1999, characterized by the dismantling not only of the centrally planned mechanism, but also of the inherited from it the large industries, transporting networks, agrarian exploitations.

b) In 2000 Romania adopted officially - with the massive support of political parties, civic organizations, and public opinion - the National Program for Integration into European Union. As a result of its implementation and of the institutional reforms conditioned by negotiations with European Commission, the Romanian economy has visibly revigorated.

c) This process has amplified after 2007, when Romania became a full member of the European Union. Consequently, the Romanian economy acquired more and more the characteristics of a functional market system. Changes induced by the transitional transformations determined a re-configuration of the sectoral structure itself.

6.2. This historical pattern can be found also in the global dynamics of the sectoral distribution of output. Based on I-O tables for 1989-2016, there were estimated the moving (Mscc) and the referential (Rscc) structural change coefficients,

$$
\begin{gathered}
\operatorname{Mssc}=\left((1 / \mathrm{n}) * \sum\left(\mathrm{w}_{\mathrm{it}}-\mathrm{w}_{\mathrm{i}(\mathrm{t}-1)}\right)^{2}\right)^{0.5} \quad(1) \text { and } \\
\operatorname{Rssc}=\left((1 / \mathrm{n}) * \sum\left(\mathrm{w}_{\mathrm{it}}-\mathrm{rw}_{\mathrm{i}}\right)^{2}\right)^{0.5}
\end{gathered}
$$

where $\mathrm{n}$ - number of sectors and $\mathrm{rw}_{\mathrm{i}}$ - sectoral shares adopted as a benchmark (in our case the year 1989- last year of the socialist regime). Both indices (1) and (1a) are plotted on the Figure no. 1.

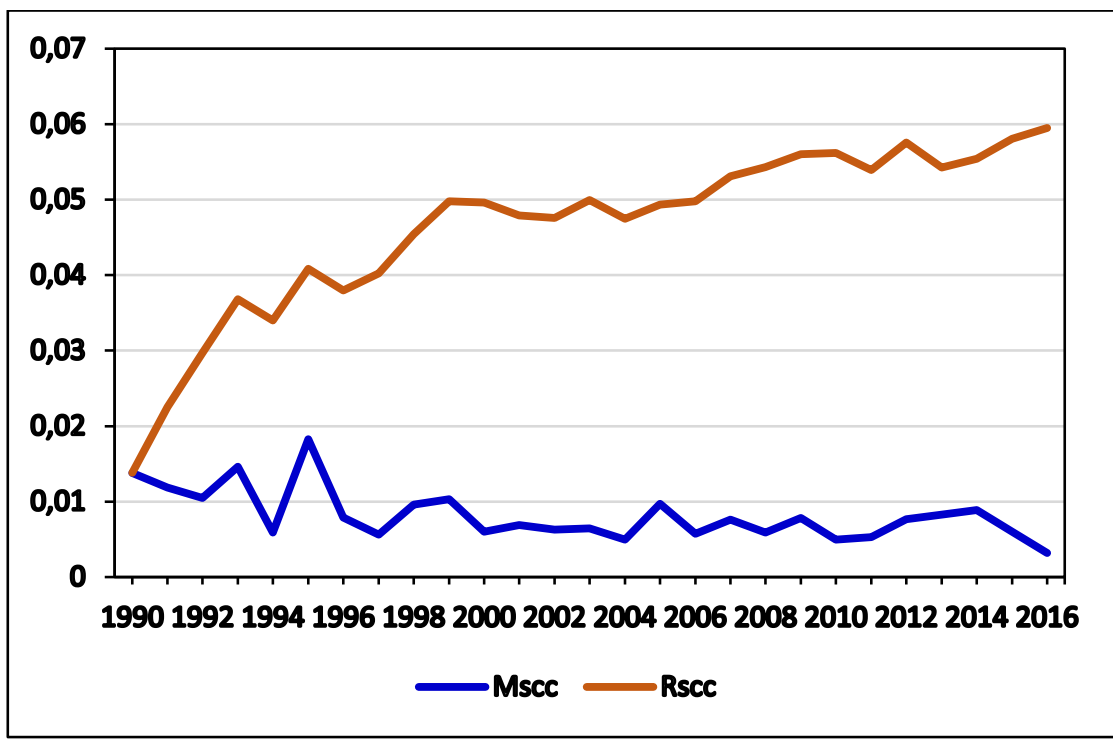

Figure no. 1: Dynamics of the sectoral structure 1990-2016 
As a mirror of the above described transitional path, the structural structure of Romanian economy again has traversed several distinct historical segments. The decade 1990-1999 is dominated by frequent and sudden sectoral shifts. We do not examine here the degree to which this restructuring process was correctly managed or not, our goal being only to evaluate its intensity. This interval was probably the most distressing stage of transition from the centrally planned to the market system.

The subsequent interval coincides with the implementation of EU pre-accession reforms. As the Figure no. 1 shows, the timespan 2000-2006 is characterized by a noticeable decline of the sectoral structure volatility.

After 2007 - especially in the context of turbulences generated by the last global crisis - the sectoral structure becomes highly fluid again. This time, however, the range of variation is more limited than in the first stage of transition. Interesting to notice that the stabilising trend produces a substantially different sectoral structure comparatively with 1989 (Rscc in Figure no. 1).

7. During this highly agitated structural process, the relative importance of different sectors in economic life $\left(\mathrm{w}_{\mathrm{ij}}\right)$ registered many - and sometimes spectacular - changes. The Appendix details the corresponding data in three moments of the post-integration period: at its beginning (2007), during the last global crisis (2010), and for the most recent I-O tables year (2016). At present, therefore, the weights $\mathrm{w}_{\mathrm{ij}}$ are ranged between zero and 0.02778 . Classified into four groups, these are characterized by the following distribution (Figure no. 2).

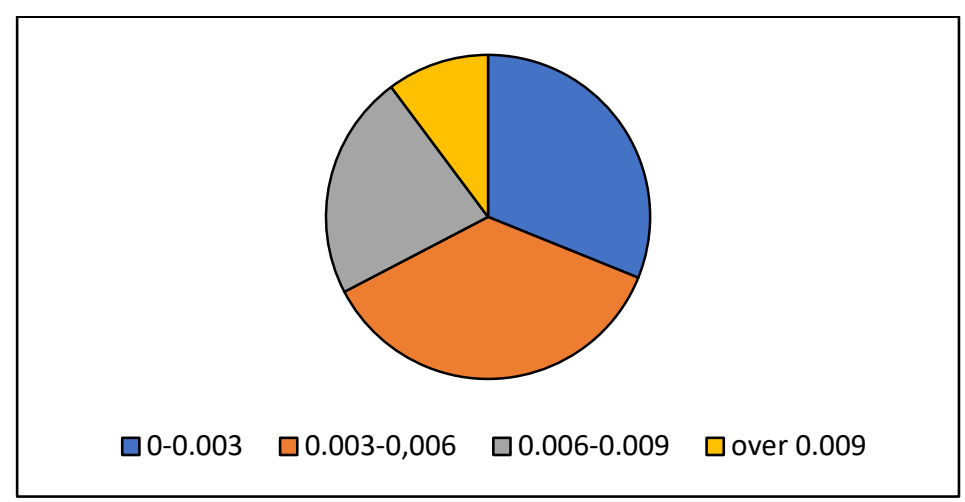

Figure no. 2: Importance weights $\left(w_{i j}\right)$ of the intra and inter-sectoral flows

Therefore, more than $10 \%$ of transactions belong to those having weights over 0.009 . Most of them gravitate around the sectors 10 (trading services) and 6 (machinery and equipment, transport means, other metal products).

8. Regarding the formula used in the estimation of $\mathrm{w}_{\mathrm{ij}}$, namely:

$$
\mathrm{w}_{\mathrm{ij}}=\left(\mathrm{q}_{\mathrm{i}} * \mathrm{q}_{\mathrm{j}}\right)^{1}
$$

two questions could be raised:

- “why product and not a simple sum?", and 
- "why the exponent 1 and not another different from unity?" The second question has been already formulated with reference to the Herfindahl-Hirschman index (Palan, 2010). The main diagonal of $\mathrm{W}$ matrix, respectively $\mathrm{q}^{2}$, represents just a $\mathrm{HH}$ type formula.

8.1. The normalizing problem is essential for the discussion of both questions.

8.1.1. An important property of the matrix $\mathrm{W}$ consists into the equality $\sum_{\mathrm{ij}} \mathrm{W}_{\mathrm{ij}}=1$. It comes from its construction. Really, the row-sums $\left(\mathrm{rw}_{\mathrm{i}}\right)$ of this matrix represent:

$$
\left.\mathrm{rw}_{\mathrm{i}}=\mathrm{q}_{\mathrm{i}} * \mathrm{q}_{\mathrm{i} 1}+\mathrm{q}_{\mathrm{i}} * \mathrm{q}_{2}+\mathrm{q}_{\mathrm{i}} * \mathrm{q}_{3}+\ldots \mathrm{q}_{\mathrm{i}} * \mathrm{q}_{\mathrm{n}}=\sum_{\mathrm{j}} \mathrm{q}_{\mathrm{ij}} \quad \text { (i-fixed; } \mathrm{j}=1,2,3, \ldots, \mathrm{n}\right)
$$

Since $\mathrm{i}=$ fixed, the expression (2) can be reorganized as:

$$
\mathrm{rw}_{\mathrm{i}}=\mathrm{q}_{\mathrm{i}} * \sum_{\mathrm{j}} \mathrm{q}_{\mathrm{j}}(3 \mathrm{a})
$$

The main assumption of our proposal was $\sum_{j} q_{j}=1$, which means that $\mathrm{rw}_{\mathrm{i}}=\mathrm{q}_{\mathrm{i}} * 1$. The sum of all $\mathrm{rw}_{\mathrm{i}}(\mathrm{srw})$ is:

$$
\mathrm{srw}_{\mathrm{i}}=\sum \mathrm{rw}_{\mathrm{i}}=\sum \mathrm{q}_{\mathrm{i}}
$$

But $\sum q_{i}$ is also equal to unity. This elementary algebra reminds the rule "sum of products as product of sums" from the vector operations. Economically this means that the importance of each intra or intersectoral transaction is expressed as a fraction of the importance of the entire set of transactions. In our algorithm, therefore, the normalization of importance assigned to positions in economy of the concerned entities ( $\mathrm{Q}_{\mathrm{i}}$ in the presented application) is sufficient to obtain the normalized values for importance of their transactions. This is not valid in possible alternative solutions.

8.1.2. In the case of addition, the above described computational succession would look as follows:

$$
\begin{gathered}
\mathrm{w}_{\mathrm{ij}}=\mathrm{q}_{\mathrm{i}}+\mathrm{q}_{\mathrm{j}} \\
\mathrm{rw}_{\mathrm{i}}=\left(\mathrm{q}_{\mathrm{i}}+\mathrm{q}_{1}\right)+\left(\mathrm{q}_{\mathrm{i}}+\mathrm{q}_{2}\right)+\left(\mathrm{q}_{\mathrm{i}}+\mathrm{q}_{3}\right)+\ldots+\left(\mathrm{q}_{\mathrm{i}}+\mathrm{q}_{\mathrm{n}}\right)=\mathrm{n}^{2} \mathrm{q}_{\mathrm{i}}+\sum_{\mathrm{j}} \mathrm{q}_{\mathrm{j}}=\mathrm{n} * \mathrm{q}_{\mathrm{i}}+1(\mathrm{j}=1,2,3, \ldots, \mathrm{n}) \quad \text { (6) } \\
\mathrm{srw}_{\mathrm{i}}=\mathrm{n} * \sum_{\mathrm{j}} \mathrm{q}_{\mathrm{j}}+\mathrm{n}=2 * \mathrm{n} \quad(7)
\end{gathered}
$$

The equality $\sum_{\mathrm{ij}} \mathrm{w}_{\mathrm{ij}}=1$ would impose, in this case, a correction of (5) by the multiplier $1 /(2 * \mathrm{n})$. Consequently, similar to the adopted by us solution, the "normalizing to unity" would need a supplementary operation.

8.1.3. Such an operation would be also necessary if the formula (5) would be

$$
\mathrm{w}_{\mathrm{ij}}=\left(\mathrm{q}_{\mathrm{i}}+\mathrm{q}_{\mathrm{j}}\right)^{\alpha}(5 \mathrm{a})
$$

in which $\alpha$ remains positive, but different from unity. It would follow:

$$
\mathrm{rw}_{\mathrm{i}}=\left(\mathrm{q}_{\mathrm{i}}+\mathrm{q}_{1}\right)^{\alpha}+\left(\mathrm{q}_{\mathrm{i}}+\mathrm{q}_{2}\right)^{\alpha}+\left(\mathrm{q}_{\mathrm{i}}+\mathrm{q}_{3}\right)^{\alpha}+\ldots+\left(\mathrm{q}_{\mathrm{i}}+\mathrm{q}_{\mathrm{n}}\right)^{\alpha}
$$

The "normalizing to unity" of results (5a) could be achieved as follows:

- by an implicit return to (5) through $\left[\left(\mathrm{q}_{\mathrm{i}}+\mathrm{q}_{\mathrm{j}}\right)^{\alpha}\right]^{1 / \alpha}$;

- or by correcting them with the multiplier $1 / \sum \mathrm{rw}_{\mathrm{i}}$.

8.1.4. A numerical example could be useful. The matrix $\mathrm{W}$ for 2016 will be computed in four variants: according to (2), (5), (5a) with $\alpha=0.95$, and (5a) with $\alpha=1.05$. Obviously, all variants 
observe the condition of "normalizing to unity". There will be plotted only the row-sums, noted correspondingly $\operatorname{srw}_{\mathrm{i}} \mathrm{A}, \mathrm{srw}_{\mathrm{i}} \mathrm{B}, \mathrm{srw}_{\mathrm{i}} \mathrm{C}$, and $\mathrm{srw}_{\mathrm{i}} \mathrm{D}$ (Figure no. 3 ).

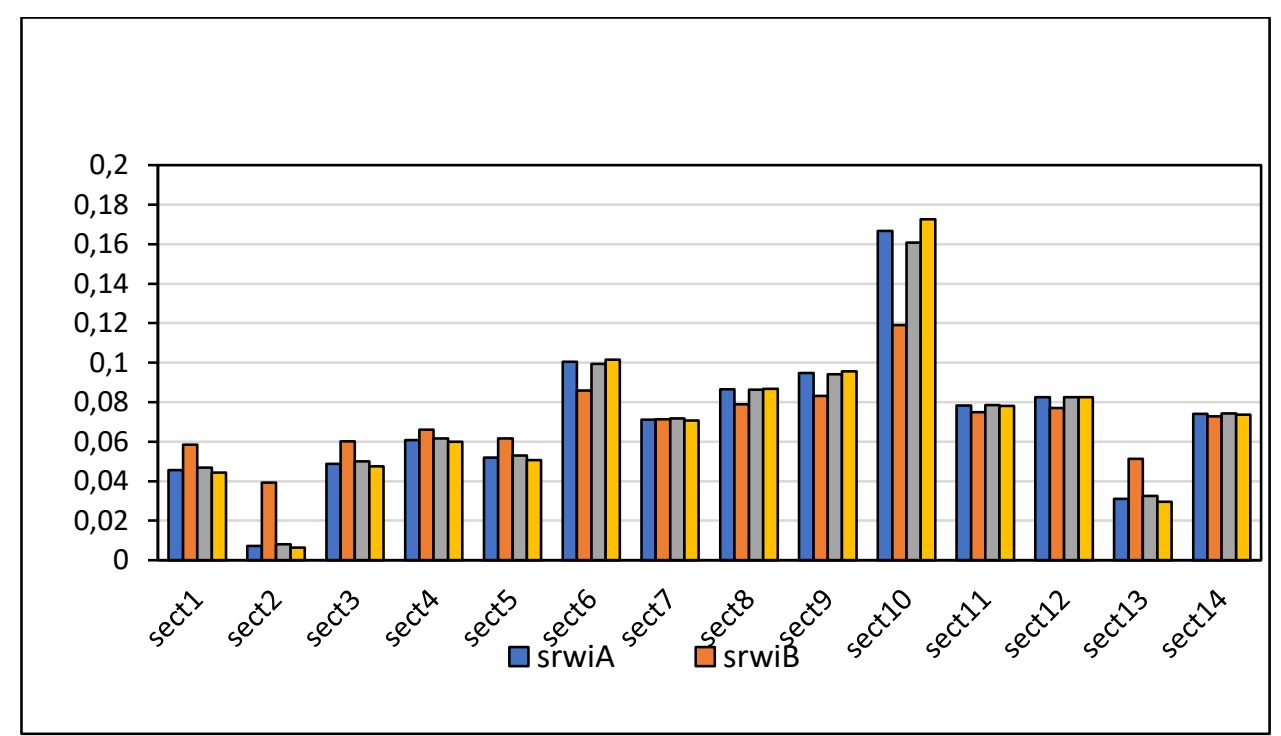

Figure no. 3: Row-sums of the matrix $W$, computed in four variants

The estimation of a normalized matrix $\mathrm{W}$, therefore, depends significantly on the chosen formula for determining initial its elements.

8.2. Implying only one „,normalizing to unity” operation, the adopted by us specification has another computational advantage. It is connected to the following question: ,how to modify the importance of a transaction ( $\mathrm{w}_{\mathrm{ijt}}$ ) if the positions (in economy) of two interacting entities $\left(\mathrm{q}_{\mathrm{i}}\right.$ and $\mathrm{q}_{\mathrm{j}}$ ) change in contrary sense, but with the same $\Delta$ ?". Obviously, assuming that both $\left(\mathrm{q}_{\mathrm{i}}\right.$ and $\mathrm{q}_{\mathrm{j}}$ ) remain non-negative.

Since the cumulated position of involved entities is constant, it seems reasonable to admit that the importance of their bilateral transaction also is constant. At any $\Delta$ ? However, not! The product allows to identify relatively easy such condition. From:

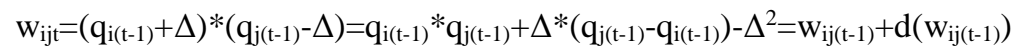

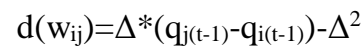

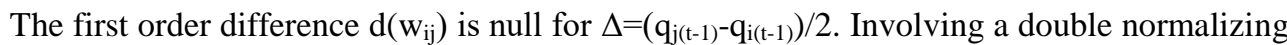
operation, other above examined specifications complicate considerably the identification of discussed here condition.

9. We finish this note observing that evaluation of interactions between economic entities through their positions (as shares) in a representative indicator is applicable in a large number of cases. Until now, to the already developed concentration analyses and to the above described algorithm for intersectoral transactions, it could be added, among many others: the inter-banking operations, regional input-output tables, foreign trade, other international flows. Our attempt, therefore, can be continued and extended. 


\section{References}

Dobrescu, E., 2006a. Integration of Macroeconomic Behavioural Relationships and the Input-Output Block (Romanian Modelling Experience). [online] Available at: <https://papers.ssrn.com/sol3/papers.cfm?abstract_id=1433357> [Accessed 20 May 2019].

Dobrescu, E., 2006b. Macromodels of the Romanian Market Economy. Bucharest: Editura Economica.

Dobrescu, E., 2015. Net Indirect Taxes and the Sectoral Structure of Economy. Romanian Journal of Economic Forecasting, 18(2), pp. 5-29.

Dobrescu, E. and Gaftea, V., 2017. The sectoral structure of an emergent economy in light of I-O analysis. In: s.n., 25th International Input-Output Association Conference. Atlantic City, New Jersey, USA, 19-23 June 2017. S.1: s.n.

European Commission, 2008. Eurostat Manual of Supply, Use and Input-Output Tables. [online] Available at: <http://ec.europa.eu/eurostat/ramon/statmanuals/files/KS-RA-07013-EN.pdf> [Accessed 14 September 2018].

Hirschman, A.O., 1958. The Strategy of Economic Development. Yale Studies in Economics. Vol.10. New Haven and London: Yale University Press.

Horowitz, K. J. and Planting, M. A., 2006. Concepts and Methods of the Input-Output Accounts. [online] U.S. Bureau of Economic Analysis of the U.S. Department of Commerce. Available

<http://www2.econ.iastate.edu/classes/crp274/swenson/URP290/Readings/IOmanual _092906BEA.pdf > [Accessed 23 September 2016].

INS, 2016. CON111A - Tabelul intrari - iesiri, echilibrul resurse - utilizari pe produse, preturi curente - SEC 2010 - CAEN Rev.2. [online] Available at: $<$ http://statistici.insse.ro/shop/index.jsp?page=tempo3\&lang=ro\&ind=CON111A > [Accessed 9 December 2016].

Leontief, W.W., 1936. Quantitative Input and Output Relations in the Economic Systems of the United States. The Review of Economics and Statistics, 18, pp.105-125.

Leontief, W.W., 1970. Analiza input-output. Bucharest: Editura Stiintifica.

Leontief, W.W., 1986. Input-output economics. $2^{\text {nd }}$ edition. New York: Oxford University Press.

Mereuta, C., 2018. Some Microeconomic Landmarks of the Transition Process in Romania, Editura Economica, Bucharest.

Miller, R.E. and Blair, P.D., 2009. Input-Output Analysis: Foundations and Extensions. $2^{\text {nd }}$ edition. New York: Cambridge University Press.

Palan, N., 2010. Measurement of Specialization - The Choice of Indices. FIW Working Paper $N^{\circ}$ 62. [online] Available at: <https://www.fiw.ac.at/fileadmin/Documents/ Publikationen/Working_Paper/N_062-Palan.pdf> [Accessed 24 December 2018].

Stone, R., 1961. Input-Output and National Accounts. Paris: Organisation for European Economic Co-operation.

United Nations, 1999. Handbook of Input-Output Table - Compilation and Analysis. [online] Department of Economic and Social Affairs - Statistics Division, Studies in Methods, Series F No. 74. Available at: <http://unstats.un.org/unsd/publication/SeriesF/ SeriesF_74E.pdf $>$ [Accessed 23 September 2016]

U.S. Department of Justice and the Federal Trade Commission, 2010. Horizontal Merger Guidelines. [online] Available at: <https://www.ftc.gov/sites/default/files/attachments/ merger-review/100819hmg.pdf $>$ [Accessed 15 May 2019]. 
Wixted, B., Yamano, N. and Webb, C., 2006. Input-Output Analysis in An Increasingly Globalised World: Applications of OECD's Harmonised International Tables. [online] Organisation for Economic Co-operation and Development, STI/WORKING PAPER 2006/7. Available at: 〈http://www.oecd.org/science/sci-tech/37349386.pdf> [Accessed 20 September 2016].

\begin{tabular}{|c|c|c|c|c|c|c|c|c|c|c|c|c|c|c|c|}
\hline \multicolumn{16}{|c|}{$\begin{array}{l}\text { Appendix } \\
\text { Matrix W }\end{array}$} \\
\hline & $\mid \begin{array}{l}|c| \\
\text { 旁 } \\
\end{array}$ & 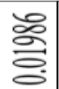 & 営 & 릉 & $\mid \begin{array}{l}\mid \overline{2} \\
2 \\
6\end{array}$ & 声 & 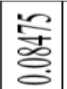 & 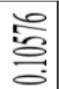 & 总 & 言 & $\frac{\tilde{E}}{\mathrm{E}}$ & 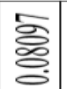 & 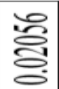 & 壱 & 总 \\
\hline & 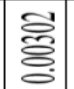 & 萦 & हై & 总 & 冚 & 帘 & 总 & 훙 & 喜 & $\mid \begin{array}{l}\overline{8} \\
0 \\
0\end{array}$ & 莺 & 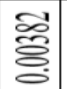 & 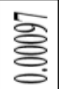 & ఫ్రి & 蒡 \\
\hline & 帘 & 营 & 言 & 흥 & ్ㅕㅇ & 咅 & 言 & $\overline{\overline{8}}$ & 总 & 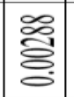 & 咅 & 总 & ్⿱艹⿹弓冫 & 产 & 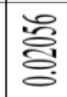 \\
\hline & 高 & 㤩 & 营 & ह్రి & 紊 & 总 & 总 & 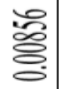 & हू & 哮 & 咅 & 莺 & 串 & 兽 & 产 \\
\hline & 产 & $\stackrel{8}{3}$ & 䓂 & 兽 & 幸 & $\overline{2}$ & 晜 & 㿣 & 兽 & $\mid$ & 紊 & 冚 & $\stackrel{\circ}{3}$ & 莺 & \\
\hline & 总 & 㣽 & 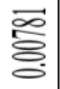 & 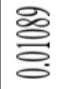 & 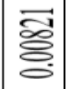 & 辰 & 㤂 & 悎 & $\overline{\overline{2}}$ & $\begin{array}{l}3 \\
2 \\
0 \\
0\end{array}$ & 官 & $\ddot{z}$ & 㤂 & 氮 & 言 \\
\hline & $\mid$ & 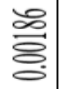 & हु' & $\overline{\underline{z}}$ & 旁 & 莺 & 趁 & 总 & 旁 & $\mid$ & 兽 & हू. & 莺 & 害 & 关 \\
\hline & E్ & 尽 & 总 & శ్ & 恶 & 莺 & 总 & $\stackrel{\Xi}{\Xi}$ & 总 & 㝘 & 㺃 & 蒿 & ్ㅗㅇ & 훙 & ? \\
\hline & 染 & $\underset{8}{\infty}$ & 害 & 莺 & 웅 & 审 & 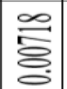 & $\begin{array}{l}\text { 号 } \\
\text { 总 }\end{array}$ & 总 & $\underset{\infty}{\infty}$ & 容 & 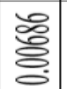 & $\stackrel{\overrightarrow{\bar{Z}}}{\mathrm{E}}$ & 总 & $\approx$ \\
\hline & 浐 & 흥 & 룽 & 条 & 善 & 总 & 总 & $\begin{array}{l}\text { 응 } \\
\stackrel{8}{8}\end{array}$ & 응 & 章 & 莺 & 鸹 & 咅 & 莺 & 喜 \\
\hline & $\begin{array}{l}\mathscr{c} \\
\tilde{\tilde{z}} \\
\delta\end{array}$ & 응 & శ్ర్రి & 旁 & 索 & 章 & 웅 & 总 & 䇺 & 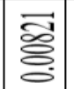 & 柔 & 壹 & ్ㅡㅇ & 咅 & 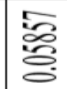 \\
\hline & 誊 & 壳 & 䓂 & 总 & 咅 & 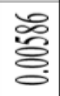 & 总 & 帘 & 言 & 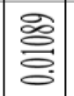 & 兽 & 宛 & 흥 & 常 & ce \\
\hline & 帘 & 五 & 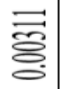 & 旁 & $\mid \begin{array}{l}\bar{Z} \\
\text { శ్ } \\
0\end{array}$ & 홍 & 害 & $\begin{array}{l}\stackrel{2}{3} \\
\stackrel{3}{8}\end{array}$ & 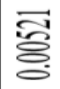 & $\mid \begin{array}{l}\vec{\infty} \\
\hat{\delta} \\
0\end{array}$ & 旁 & 总 & 吾 & 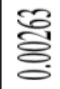 & $\Xi$ \\
\hline & 坖 & 芯 & 莺 & 壳 & 吾 & 릉 & \begin{tabular}{|l|}
0 \\
\\
\end{tabular} & 怘 & 㚆 & 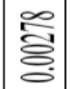 & 릉 & 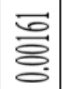 & 暯 & 总 & \% \\
\hline & 产 & ్ㅡㅇ & 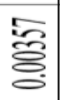 & 웅 & 瓷 & 呇 & 䓫 & E⿱宀㠯心㔾 & 兽 & $\mid \begin{array}{l}0 \\
0 \\
0 \\
0 \\
0\end{array}$ & 产 & 产 & శ్ & 窠 & 产 \\
\hline & 丞 & 己్ల్ర & $\mathscr{D}$ & $\mathscr{E}$ & $\mathscr{D}$ & 릉 & 呇 & 俤 & $\mathscr{\mathscr { D }}$ & 胥 & 焉 & 泾 & 氶 & 莺 & 氶 \\
\hline
\end{tabular}




\begin{tabular}{|c|c|c|c|c|c|c|c|c|c|c|c|c|c|c|c|}
\hline & 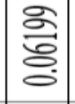 & 产 & 悤 & $\mid \begin{array}{l}0 \\
0 \\
0 \\
0 \\
0\end{array}$ & 吾 & శ్ & 产 & 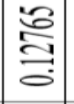 & 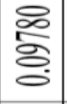 & 营 & 咅 & E. & 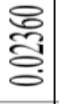 & 营 & 条 \\
\hline & 言 & 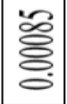 & శ్ & 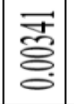 & 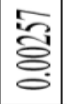 & 营 & 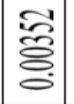 & 总 & 旁 & 离 & 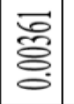 & 을 & $\stackrel{\infty}{\stackrel{0}{8}}$ & ఫ్ర్ & 莺 \\
\hline & 亳 & 웅ㅇㅇㅇ & 㗼 & 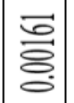 & 콩 & 응 & 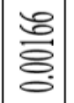 & 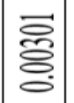 & $\overrightarrow{\widehat{\Xi}}$ & 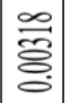 & 응 & 을 & 㤂 & 号 & 员 \\
\hline & 官 & ठิ & 总 & 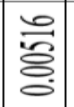 & 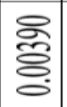 & 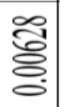 & 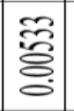 & 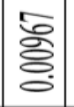 & 营 & 总 & 莺 & 壹 & 흥 & 命 & E \\
\hline & 善 & 意 & 䔅 & 产 & 宮 & 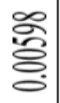 & 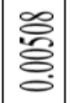 & 帘 & 응 & 点 & 灾 & 言 & 릉 & 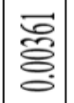 & $\varepsilon$ \\
\hline & 芯 & 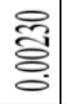 & 总 & 흥 & 灾 & 百 & 옹 & 至 & $\begin{array}{l}\infty \\
\stackrel{\infty}{3} \\
\stackrel{8}{8}\end{array}$ & 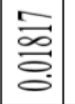 & 彦 & $\mid \begin{array}{l}\bar{\Xi} \\
\bar{O}\end{array}$ & $\begin{array}{l}\infty \\
\stackrel{\infty}{8} \\
0\end{array}$ & 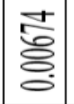 & \\
\hline & 悤 & 흥 & 㻤 & $\mid \begin{array}{l}\mid \\
0 \\
0 \\
0 \\
0\end{array}$ & 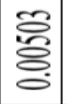 & 葸 & 客 & 号 & 㕆 & $\mid \begin{array}{l}\infty \\
\stackrel{\overrightarrow{2}}{0} \\
\end{array}$ & 릉 & 吾 & శ్త్రి & 产 & 㾸 \\
\hline & 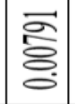 & 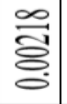 & 产旁 & $\mid \begin{array}{l}0 \\
0 \\
0 \\
0 \\
0 \\
0\end{array}$ & 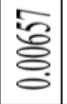 & 芯 & 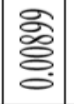 & 8 & $\begin{array}{l}\text { 울 } \\
\text { 영 }\end{array}$ & 8 & 突 & 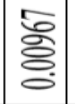 & 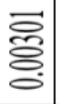 & ह્ઢ & $a$ \\
\hline & 厗 & ్ㅡㅇ & 产 & 웋영 & 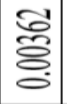 & $\begin{array}{l}\text { 䓤 } \\
\text { }\end{array}$ & 产 & 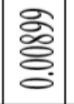 & 灾 & 高 & $\begin{array}{l}0 \\
0 \\
0 \\
0 \\
0 \\
0\end{array}$ & 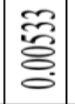 & 영 & 芯 & 咅 \\
\hline & 臺 & 家 & 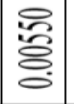 & 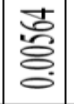 & 悹 & 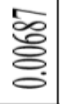 & 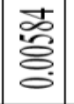 & 8 & 鸹 & 㤩 & 总 & $\mid$\begin{tabular}{l}
$\infty$ \\
\multirow{3}{8}{} \\
0 \\
0
\end{tabular} & 응 & 产 & $\stackrel{a}{a}$ \\
\hline & 产 & 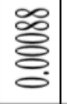 & 莺 & 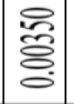 & 芯 & ్ㅗㅇ & & 原 & $\begin{array}{l}\text { 令 } \\
\text { 灾 }\end{array}$ & శ్ర్రి & 突 & 总 & ్ㅗㅇ & క్రి & $a$ \\
\hline & 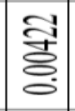 & 象 & 旁 & శ్రి & 命 & 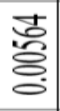 & $\frac{\Omega}{\vec{g}}$ & $\mid \begin{array}{l}0 \\
0 \\
0 \\
0 \\
0 \\
0\end{array}$ & | & $\overline{\bar{g}}$ & 产 & $\mid \begin{array}{l}0 \\
\ddot{2} \\
0 \\
0\end{array}$ & $\begin{array}{l}\overrightarrow{6} \\
\overrightarrow{8}\end{array}$ & 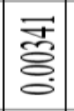 & do \\
\hline & 营 & 응 & 劧 & 产 & 急 & 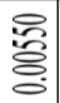 & 总 & 㥶 & 웅 & 关 & 鸹 & 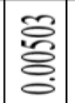 & 흥 & 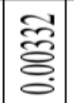 & 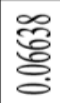 \\
\hline & 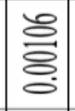 & ్ㅗㅇㅇㅇ. & 咅 & 高 & 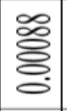 & $\underset{8}{\overrightarrow{8}}$ & $\underset{\overparen{8}}{\overparen{8}}$ & $\begin{array}{l}\infty \\
\overline{8} \\
\delta\end{array}$ & 흥 & శ్శ్రి & $\begin{array}{l}\Omega \\
\tilde{B} \\
\end{array}$ & 斊 & 旁 & 苂 & $\ddot{g}$ \\
\hline & 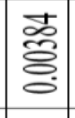 & 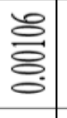 & 言 & 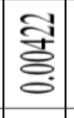 & 总 & 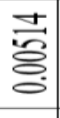 & 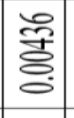 & $\mid$\begin{tabular}{|c|}
$\overline{\bar{\sigma}}$ \\
$\bar{\delta}$
\end{tabular} & 象 & 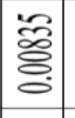 & 旁 & 㺃 & $\frac{0}{3}$ & 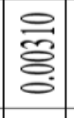 & $c$ \\
\hline & 荧 & 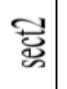 & 总 & 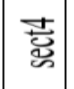 & "丞 & $\mathscr{W}$ & 芯 & $\mathscr{\mathscr { c }}$ & 密 & 悤 & 焉 & ב్ & 胥 & 志 & \\
\hline
\end{tabular}




\begin{tabular}{|c|c|c|c|c|c|c|c|c|c|c|c|c|c|c|c|}
\hline & & & \& & & & & & & & 30 & & & & & \\
\hline & & סל & 8 & & & & & & & & & - & & & \\
\hline & & 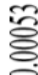 & ర్ర్రి & & ర్ర్రి & 妾 & 8 & 雱 & & 志 & & క్రి & & 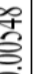 & 尌 \\
\hline & & & $\Omega$ & & 6 & $\vec{c}$ & $\tilde{Z}$ & 8 & 2 & & 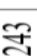 & $\therefore$ & & $\overline{7}$ & ఏ \\
\hline & & 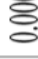 & 응 & & 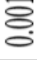 & 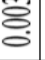 & 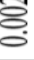 & 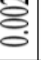 & & 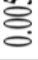 & 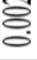 & ઠి. & & & 8 \\
\hline & & & $\frac{\beta}{\beta}$ & & ఫे & ઠ్రి & 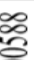 & 士 & $\tilde{\mathscr{\infty}}$ & $\frac{2}{m}$ & 8 & ㅇㅇㅇ & ๕ั้ & s & 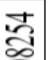 \\
\hline & & & 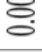 & & 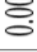 & 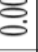 & E & 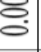 & 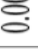 & $\therefore$ & 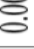 & co & 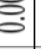 & & \\
\hline & & 5 & శ్ & & 훙 & ద & & $\stackrel{\infty}{8}$ & $\tilde{F}$ & "ֶ̨̌ & $\ddot{8}$ & 웅 & & $\bar{d}$ & \\
\hline & & 8 & 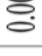 & & & 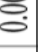 & 8 & 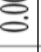 & $\sigma$ & 8 & 8 & 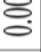 & & & \\
\hline & & 경 & 声 & & జః & $\frac{ \pm}{6}$ & $\infty$ & 寻 & $\stackrel{\circ}{\stackrel{\circ}{a}}$ & $\stackrel{\infty}{E}$ & 28 & 㒸 & $\bar{z}$ & $\exists$ & 8 \\
\hline & & 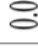 & ర. & & . & 8 & 8 & 8 & $\approx$ & 8 & 8 & 용 & 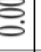 & & \\
\hline & & 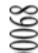 & 웅 & & 홍 & గ్రి & $\frac{0}{8}$ & శ్ & ஜ̊ & $\stackrel{\text { }}{\stackrel{\text { }}{?}}$ & 学 & 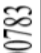 & ઠิે & & \\
\hline & & & 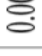 & 7 & . & 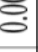 & $\underset{8}{8}$ & '. & 8 & 8 & 8 & 8 & & & \\
\hline & & 8 & $\widetilde{\tilde{c}}$ & & 导 & $\begin{array}{l}\text { ठे. } \\
8\end{array}$ & $\frac{0}{8}$ & 守 & శ্ঠ & 寻 & $\stackrel{\infty}{8}$ & 吉 & క్రి & 영 & \\
\hline & & 8 & S. & & 8 & 8 & 8 & '. & 0 & 8 & $\stackrel{8}{\circ}$ & 8 & 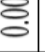 & & \\
\hline & & $\overline{8}$ & 串 & & 용 & $\frac{0}{5}$ & ర్రి & $\begin{array}{l}0 \\
8\end{array}$ & हैँ & $\stackrel{\infty}{=}$ & $\therefore$ & 兑 & క్ & & \\
\hline & & 8 & م. & & 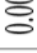 & 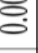 & 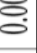 & 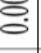 & 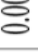 & 8 & ¿. & 8 & 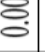 & $\bar{\theta}$ & 0 \\
\hline & & 8 & $\overrightarrow{\vec{c}}$ & $=$ & 종 & 흐 & 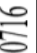 & రి & $\approx$ & ț & 冓 & ઠે & & & \\
\hline & & 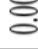 & 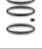 & $c$ & 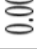 & 8 & . & : & 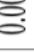 & 8 & ס. & & סֶ. & E & \\
\hline & & ชิ & 売 & - & 응 & รี & हి & 守 & $\widehat{\vartheta}$ & రి & ş & ఫેํํ & & & \\
\hline & & 8 & ᄋ. & 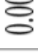 & . & : & 8 & 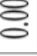 & 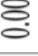 & 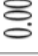 & ¿ & 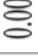 & 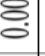 & & 8 \\
\hline & & \pm & Б్రి & $\tau$ & 용 & $\varnothing$ & ซิ & కొ & $E$ & 흥 & 屉 & క్రి & & & \\
\hline & & 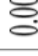 & 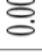 & & 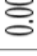 & 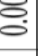 & 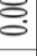 & 8 & 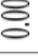 & 8 & $\bar{\Xi}$ & 8 & 8 & & 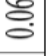 \\
\hline & & & శ్ & & 売 & 至 & of & శิ & $\sqrt{3}$ & 㕝 & ઝ & 宇 & & & \\
\hline & & 0 & 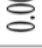 & & 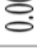 & $\delta$ & & 0 & 0 & 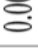 & 8 & 8 & & & \\
\hline & & 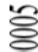 & $\tilde{\delta}$ & & $\tilde{\delta}$ & 동 & $\overline{8}$ & ర్రి & 8 & ్ㅡㄹ & ஜ̌́ & ஜூ & & & \\
\hline & & 0 & 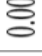 & & 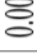 & ర్ & 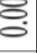 & : & & 8 & 0 & 8 & & & 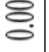 \\
\hline & & $\hat{8}$ & $\approx$ & & $\tilde{8}$ & $\stackrel{2}{2}$ & 1 & ס & & $\frac{8}{8}$ & $\tilde{\varepsilon}$ & $\frac{2}{2}$ & & & \\
\hline & & & 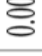 & & 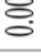 & 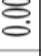 & & 8 & & 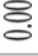 & & 8 & & & \\
\hline & & & $\mathscr{D}$ & & & & & $\infty$ & & 을 & & ్ㅡㅇ & $\frac{m}{\bar{Z}}$ & & \\
\hline
\end{tabular}

